\title{
DEVELOPMENT OF GEOINFORMATION SYSTEM FOR IDENTIFICATION AND TIME MONITORING OF DAMAGED LANDS DUE TO ILLEGAL EXTRACTION OF AMBER
}

\author{
Oleksandr YANCHUK (D)*, Tetiana DETS (D), Olha DMYTRIV ${ }^{\circledR}$, Serhii OSTAPCHUK (D), \\ Andrii PROKOPCHUK ${ }^{\mathbb{D}}$, Serhii TROKHYMETS ${ }^{\mathbb{D}}$, Ruslan YANCHUK ${ }^{\mathbb{D}}$ \\ Department of Geodesy and Cartography, Educational and Scientific Institute Agroecology and Land \\ Management, National University of Water and Environmental Engineering, Rivne, Ukraine
}

Received 17 September 2019; accepted 15 September 2020

\begin{abstract}
On basis of the analysis of existing elaborations determining places of the illegal extraction of amber by data of remote sensing of the Earth were established basic deciphering signs of the phenomenon researched. Methods were developed to identify lands damaged as a result of the illegal extraction of amber taking into account the specifics of data processing obtained from different types of satellite surveying systems: WorldView-2/3, Pleiades-1, Spot-6/7, Planet Scope, Sentinel-2B. The structure is substantiated and modular geoinformation system was developed on basis of GIS QGIS with added modules from open libraries GDAL, GRASS. The developed methods and modules of geoinformation system were tested on researched testing grounds with automated identification and calculation of areas of damaged lands.
\end{abstract}

Keywords: illegal extraction of amber, damaged lands, multi-spectral satellite photos, indexed and composite images, QGIS, geoinformation system of lands monitoring.

\section{Introduction}

Main deposits of Ukrainian amber are concentrated in the Prypyat basin which embraces northern regions of Volyn, Rivne, Zhytomyr and Kyiv provinces.

During last ten years substantial land areas in these regions underwent significant negative impact from illegal amber extraction. This leads to the great damage to Ukrainian economy and region nature, in particular, causes the damaged structure of relief and natural landscapes, worsens the ecological state of soils, stipulates negative changes in the regime of surface and underground waters and destruction of forests (Naumeth, 2014).

\section{Analysis of research}

The dominant majority of areas of illegal amber extraction is on little admissible closed by forests and bushes territories faraway from settlements and passable parte. Besides, such areas are very often protected by persons of unknown subordination who prevent from the admission to them with the aim of determining amounts of damaged lands by land methods.
Therefore, the problem of revealing territories of illegal amber extraction and the determination of their areas with the help of data of the remote sensing of the Earth is at present extremely pressing. Main elaborations in this direction are postulated in works of experts of SD Scientific centre of aero-cosmic researches of Earth under of Ukraine (V. S. Filipovych, M. S. Lubsky, G. B. Krylova) (Filipovych, 2015a, 2015b; Filipovych et al., 2015; Filipovych \& Shevchuk, 2016), Institute of telecommunications and global information space of Ukraine (V. O. Okharev) (Okharev, 2016). National university of water and environmental engineering (R. M. Yanchuk, A. V. Prokopchuk, S. M. Trokhymets) (Yanchuk et al., 2017), State enterprise "Designing bureau "Pivdenne named after M. K. Yangel” (V. N. Masley, K. G. Belousov, V. S. Khoroshylov, N. G. Galych), Dnepropetrivsk national university named after O. Gonchar (D. K. Mozgovy, A. S. Bushanska) (Masley et al., 2016).

In these works the possibilities are researched of using multi-zonal satellite images to discover areas of illegal extraction on basis of texture, spectral and temperature differences of sand dumps from surrounding environment objects. The dynamics was studied of creating such dumps

${ }^{*}$ Corresponding author. E-mail: o.e.yanchuk@nuwm.edu.ua 
by way of determining areas of damaged lands during the continuous period using time-different cosmic images. The problem was investigated of verifying data of remote sensing of the Earth by way of choosing samples of surface dumps for spectral analysis.

In spite of existing elaborations in the direction of the research at present there was not developed a distinct algorithm of practical implementation of identification process and monitoring of lands damaged as a result of amber extraction which could permit to automatically define the localization and area of such lands, to carry out the monitoring of the phenomenon in time and to assess scopes of losses of natural resource potential.

\section{Research methods}

The aim of this work is to develop methods pf processing remote sensing from different sensors and to create a geoinformation system for automatic identification and time monitoring of lands damaged as a consequence of illegal amber extraction. This will permit to carry out the assessment of the scopes of illegal amber extraction, to determine areas of damaged lands and necessary volumes of recultivation.

The illegal extraction of amber is being done in various natural landscape conditions and by different methods which, in its turn, influences the interpretation properties of surveyed material.

Main deciphering characteristics of places of the illegal amber extraction on cosmic images is the availability of areas of alternating open dumps of sand and dug holes which possess a characteristic spectral image, small cell texture of image and temperature contrast with surrounding vegetation.
In the capacity of additional deciphering characteristic of deploying places of illegal amber extraction may serve the availability of the chaotic network of canals used for supplying water while applying hydro-pump method of mining.

Besides, an efficient method of deciphering places of illegal amber extraction is the analysis of the dynamics of landscape changes on basis of using different temporal photos of the same territory.

The possibility and validity of discovering damaged plots depends on the data of conducting elaborations. With time damaged plots are restored partially and are covered with vegetation the result of which their interpretation properties worsen at the expense of decreased contrast with surrounding non-damaged environment.

Considering the above mentioned factors it is possible to draw a conclusion that for identifying plots damaged due to the illegal amber extraction it is necessary to use various approaches and different cosmic images. To basic characteristics of material of remote sensing which influence the quality of deciphering and stipulate the selection of the method of automated classification belong space, radiometric, spectral and temporal resolution, and also the level of processing photos and the preciseness of a geographic survey.

With the aim of studying the possibility of identifying damaged lands under different natural conditions and ways of extraction we chose 5 testing plots with different geographic deployment. Plots are situated in the northern part of Rivne and Zhytomyr provinces, in particular, on the territory of Zarichne, Dubrovytsya, Sarny and Rokytne districts of Rivne province and Olevsk district of Zhytomyr province (Figure 1).

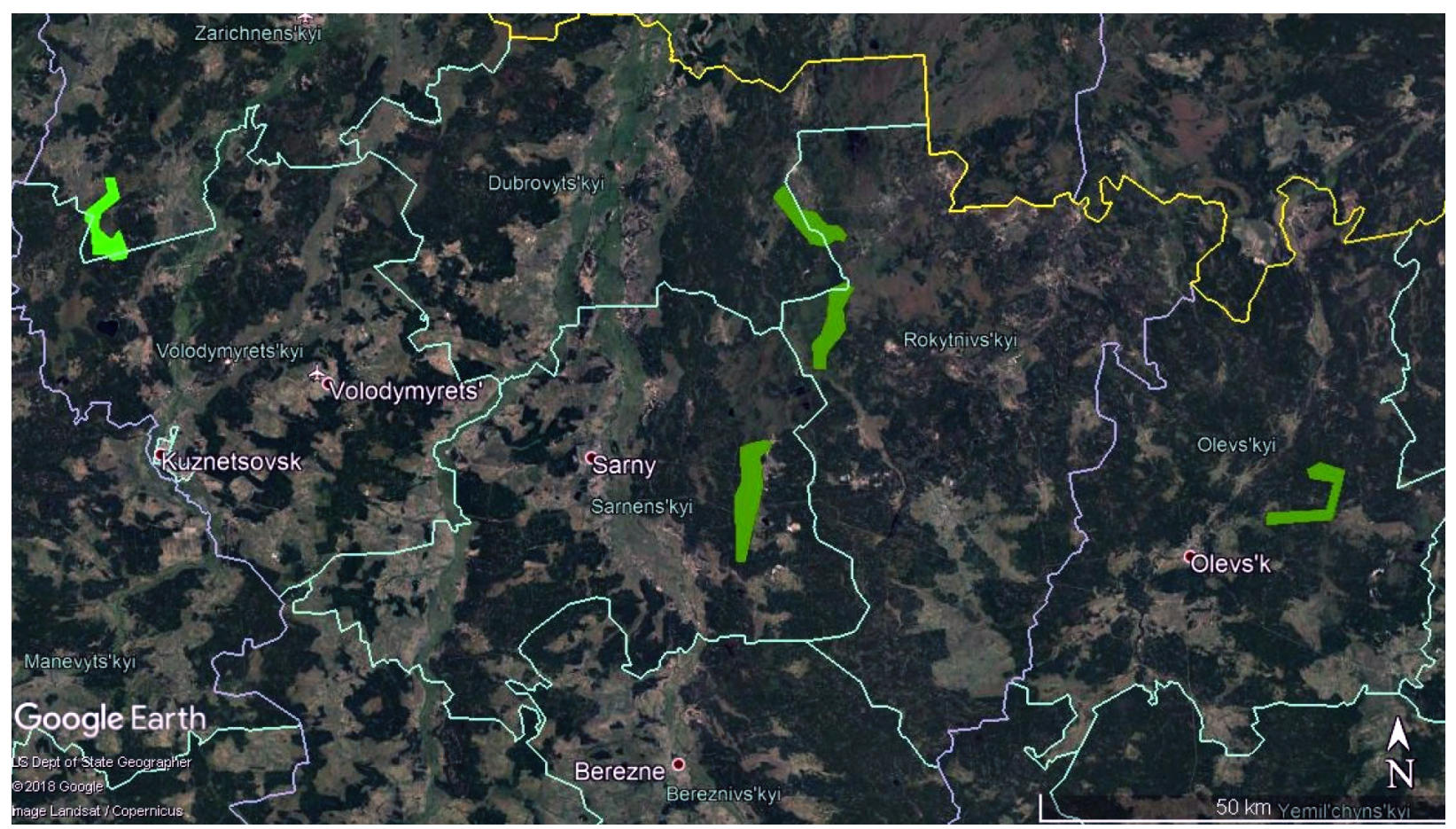

Figure 1. Deployment of masses of testing plots on researched territory 
In the process of determining deciphering characteristics and selecting optimal materials of remote sensing images were researched with different resolution (space, radiometric, spectral ones). In our development were included data obtained from cosmic apparatuses WorldView-2, World-View3 (Digital Globe Inc., USA), Pleiades-1 (AIRBUS, France), Spot-6/7 (AIRBUS, France), Planet Scope (Planet Labs, Inc., USA), Sentinel-2A/2B (AIRBUS, France). Their main characteristics are presented in Table 1.

Taking into account various temporal coverage and minimum areas requested for different surveying systems data sets formed for each testing plot differ by sources, areas and configuration.

The processing of data of remote sensing includes standard stages such as preparation, preliminary processing, thematic processing of data, comprehensive analysis of results. At the same time, the practical implementation of these stages depends on hardware and software.

Technological scheme of processing data is presented in Figure 2.

The paper draws data sets obtained both by free of charge satellite missions and also by commercial systems. The unification of data at the stage of thematic processing

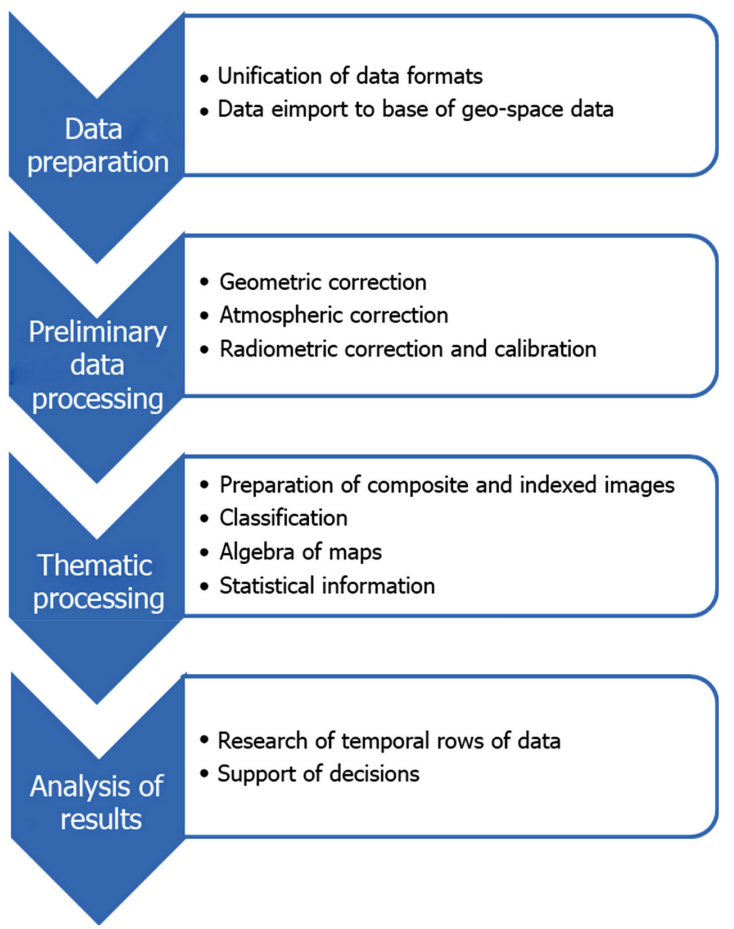

Figure 2. Technological scheme of processing images

Table 1. Main characteristics and sources of receiving data of remote sensing

\begin{tabular}{|c|c|c|c|c|c|c|}
\hline \multirow{5}{*}{$\begin{array}{l}\text { Area of } \\
\text { interest }\end{array}$} & \multirow{2}{*}{$\begin{array}{l}\text { Characteristics } \\
\text { Satellite system }\end{array}$} & \multicolumn{5}{|c|}{ Dates of remote sensing of the Earth } \\
\hline & & WorldView-2/3 & Pleiades-1 & Spot-6/7 & Planet Scope & Sentinel-2B \\
\hline & Channels & $\begin{array}{l}\text { Panhromatic (1) } \\
\text { R, G, B, NIR, } \\
\text { coastal, yelow, } \\
\text { red edge, NIR- } \\
2(2)\end{array}$ & $\begin{array}{l}\text { PSM 4-bands: } \\
\text { R, G, B, NIR }\end{array}$ & $\begin{array}{l}\text { PSM 4-bands: } \\
\text { R, G, B, NIR }\end{array}$ & $\begin{array}{l}\text { PSM 4-bands: } \\
\text { R, G, B, NIR }\end{array}$ & $\begin{array}{c}\text { R, G, B, NIR (1) } \\
4 \text { Vegetation red edge, } \\
2 \text { SWIR(2) } \\
\text { Coastal aerosol, Water } \\
\text { vapour, SWIR - Cirrus(3) }\end{array}$ \\
\hline & $\begin{array}{l}\text { Radiometric } \\
\text { resolution }\end{array}$ & $16 \mathrm{bit} / \mathrm{px}$ & $16 \mathrm{bit} / \mathrm{px}$ & $16 \mathrm{bit} / \mathrm{px}$ & $16 \mathrm{bit} / \mathrm{px}$ & $11 \mathrm{bit} / \mathrm{px}$ \\
\hline & Data source & "TVIS Ukraine" & $\begin{array}{l}\text { "TVIS } \\
\text { Ukraine" }\end{array}$ & $\begin{array}{l}\text { “TVIS } \\
\text { Ukraine" }\end{array}$ & $\begin{array}{c}\text { www.planet. } \\
\text { com }\end{array}$ & $\begin{array}{l}\text { www.scihub. } \\
\text { copernicus.eu }\end{array}$ \\
\hline \multirow{2}{*}{$\begin{array}{l}\text { AOI } 1 \\
\text { (Sarny } \\
\text { district Rivne } \\
\text { province) }\end{array}$} & Date of surveying & 28.04 .2018 & 20.08 .2016 & 24.03 .2015 & 03.05 .2018 & 29.04 .2018 \\
\hline & Spatial resolution & $\begin{array}{l}\text { (1) } 0.5 \mathrm{~m} / \mathrm{px} \\
\text { (2) } 2.0 \mathrm{~m} / \mathrm{px}\end{array}$ & $0.92 \mathrm{~m} / \mathrm{px}$ & $1.5 \mathrm{~m} / \mathrm{px}$ & $3.0 \mathrm{~m} / \mathrm{px}$ & $\begin{array}{l}\text { (1) } 10 \mathrm{~m} / \mathrm{px} \\
\text { (2) } 20 \mathrm{~m} / \mathrm{px} \\
\text { (3) } 60 \mathrm{~m} / \mathrm{px}\end{array}$ \\
\hline \multirow{2}{*}{$\begin{array}{l}\text { AOI } 2 \\
\text { (Rokytne } \\
\text { district Rivne } \\
\text { province) }\end{array}$} & Date of surveying & $\begin{array}{l}31.10 .2015 \\
28.04 .2018 \\
\end{array}$ & 07.09 .2016 & 17.05.2017 & $\begin{array}{l}21.04 .2018 \\
03.05 .2018 \\
\end{array}$ & 29. 04.2018 \\
\hline & Spatial resolution & $\begin{array}{l}\text { (1) } 0.5 \mathrm{~m} / \mathrm{px} \\
\text { (2) } 2.0 \mathrm{~m} / \mathrm{px}\end{array}$ & $0.74 \mathrm{~m} / \mathrm{px}$ & $1.5 \mathrm{~m} / \mathrm{px}$ & $3.0 \mathrm{~m} / \mathrm{px}$ & $\begin{array}{l}\text { (1) } 10 \mathrm{~m} / \mathrm{px} \\
\text { (2) } 20 \mathrm{~m} / \mathrm{px} \\
\text { (3) } 60 \mathrm{~m} / \mathrm{px}\end{array}$ \\
\hline \multirow{2}{*}{$\begin{array}{l}\text { AOI } 3 \\
\text { (Dubrovytsya } \\
\text { district Rivne } \\
\text { province) }\end{array}$} & Date of surveying & 11.09 .2016 & & 14.10 .2016 & 03.05 .2018 & 29.04 .2018 \\
\hline & Spatial resolution & $\begin{array}{l}\text { (1) } 0.5 \mathrm{~m} / \mathrm{px} \\
\text { (2) } 2.0 \mathrm{~m} / \mathrm{px}\end{array}$ & & $1.5 \mathrm{~m} / \mathrm{px}$ & $3.0 \mathrm{~m} / \mathrm{px}$ & $\begin{array}{l}\text { (1) } 10 \mathrm{~m} / \mathrm{px} \\
\text { (2) } 20 \mathrm{~m} / \mathrm{px} \\
\text { (3) } 60 \mathrm{~m} / \mathrm{px}\end{array}$ \\
\hline \multirow{2}{*}{$\begin{array}{l}\text { AOI } 4 \\
\text { (Zarichne } \\
\text { district Rivne } \\
\text { province) }\end{array}$} & Date of surveying & & 06.04 .2014 & 23.11 .2017 & 04.05 .2018 & 29.04 .2018 \\
\hline & Spatial resolution & & $0.85 \mathrm{~m} / \mathrm{px}$ & $1.5 \mathrm{~m} / \mathrm{px}$ & $3.0 \mathrm{~m} / \mathrm{px}$ & $\begin{array}{l}\text { (1) } 10 \mathrm{~m} / \mathrm{px} \\
\text { (2) } 20 \mathrm{~m} / \mathrm{px} \\
\text { (3) } 60 \mathrm{~m} / \mathrm{px}\end{array}$ \\
\hline \multirow{2}{*}{$\begin{array}{l}\text { AOI } 5 \\
\text { (Olevsk dist- } \\
\text { rict Zhytomyr } \\
\text { province) }\end{array}$} & Date of surveying & & 18.10 .2016 & 29.04 .2016 & 23.04 .2018 & 29.04 .2018 \\
\hline & Spatial resolution & & $0.85 \mathrm{~m} / \mathrm{px}$ & $1.5 \mathrm{~m} / \mathrm{px}$ & $3.0 \mathrm{~m} / \mathrm{px}$ & $\begin{array}{l}\text { (1) } 10 \mathrm{~m} / \mathrm{px} \\
\text { (2) } 20 \mathrm{~m} / \mathrm{px} \\
\text { (3) } 60 \mathrm{~m} / \mathrm{px}\end{array}$ \\
\hline
\end{tabular}




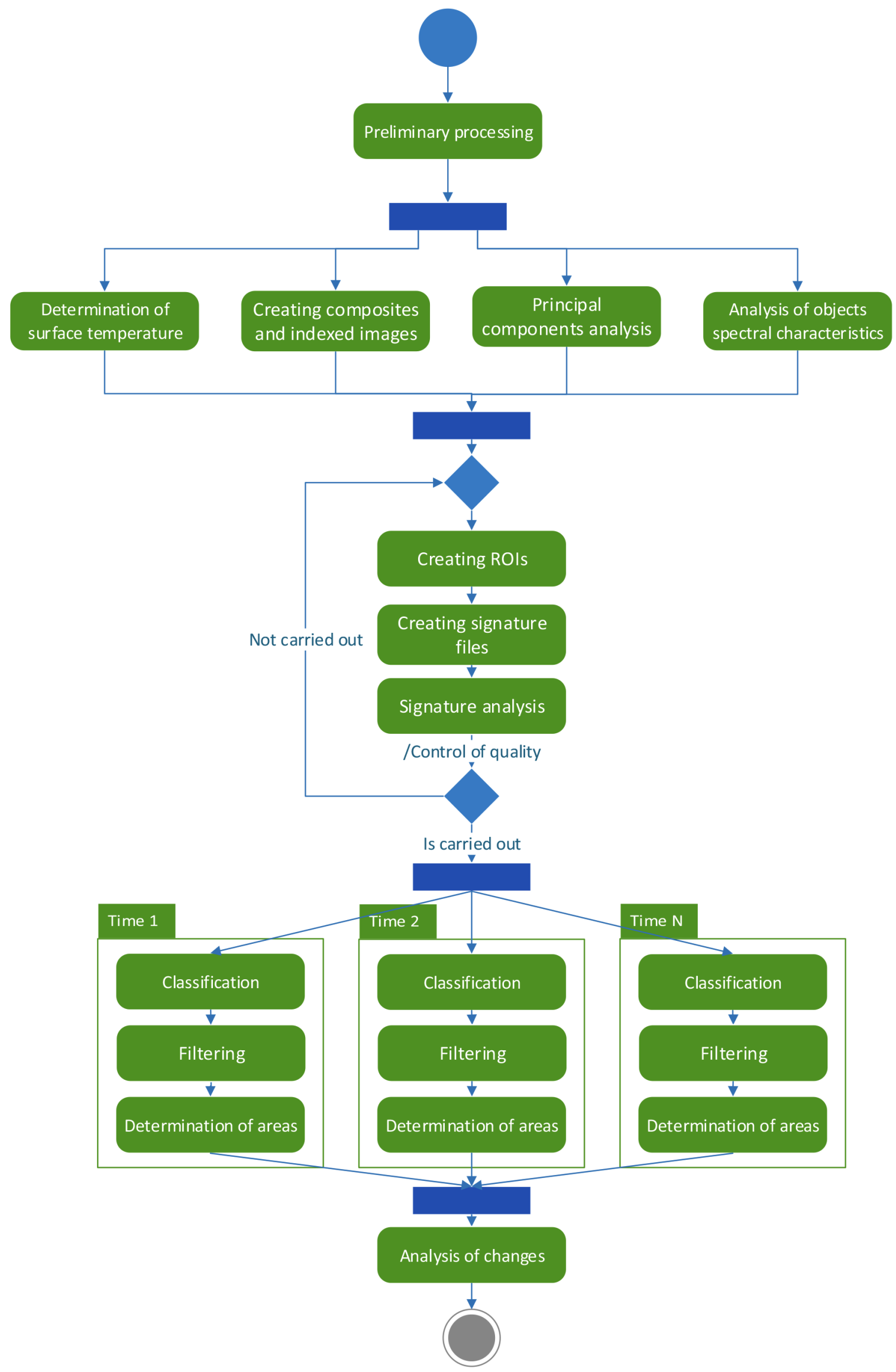

Figure 3. Methods of determining areas of damaged lands by satellite photos 
is rather important. Depending on the level of processing the process of data preparation will somewhat differ.

By the method of data preparation they may be divided into some groups.

To the first group belong satellite photos VW2, VW3 for which at the stage of preliminary processing there emerges a need in carrying out the process of panchromatic consolidation - the enlargement of images resolution with the help of panchromatic channel (Pansharpening ..., n.d.). This procedure permits to increase space resolution pf photos by 2-3 times depending on surveying systems.

To the second group belong data received by scientific satellite missions Sentinel (ESA, n.d.) and others. Images obtained by such systems have rather significant space coverage due to which are able to embrace all territory of studies. The process of developing such data is the simplest because practically all modern table GIS have the instrumentation for working with them.

For the more qualitative processing of this group rasters it is necessary to carry out their re-discretization (reducing values of pixels of all channels to the same size) and cut out study sphere.

To the third group there may belong data collected by systems Pleaides-1A, SPOT-6. Such photos require only ortho-rectification and atmospheric correction.

To a separate group belong images obtained by PlanetScope satellites. In connection with the fact that they have the size of $8 \times 25 \mathrm{~km}$ and not always completely cover the researched territory it is necessary to conduct "sewing together" several images after which using vector masks single out the necessary region.

After completing the preliminary processing all data are stored in format GeoTIFF (coordinate system UTM$35 \mathrm{~N})$.

Methods of discovering and mapping plots of illegal amber extraction consist in the subsequent analysis of multispectral cosmic data on basis of classification, including the consideration for temperature and indexed indicators.

Methods of determining areas of purposeful plots of damaged lands are presented in Figure 3.

For determining surface temperature it is most expedient to use data obtained by TIRS senser of Landsat 8 satellite (NASA, n.d.). The development of such data includes a series of stages presented in Figure 4 (Prokopchuk et al., 2018). The temperature of land surface was determined by indicators of channel 10 .

To increase the quality of deciphering and classification is possible using indexed images and color composites. The list of composites and indexed maps used in the process of geoinformation analysis is given in publication (Yanchuk et al., 2017). By obtained values of vegetation indices it is possible to more exactly to identify the open soil cover. The use of composites constructed using data collected in short-range and middle-range infrared sections of specter will permit to identify hidden in the visible specter section surface peculiarities.

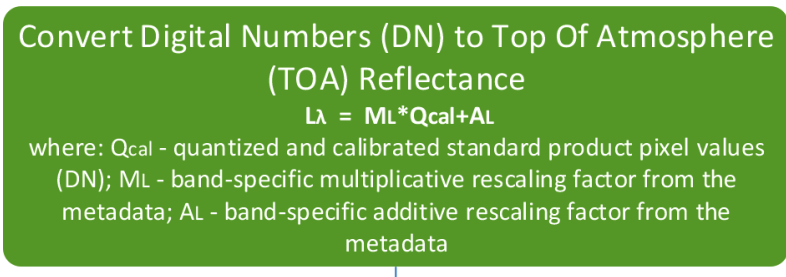

Conversion to Top of Atmosphere Brightness

Temperature

$\mathrm{TB}_{\mathrm{B}}=\mathrm{K} 2 / \ln (1+\mathrm{K} 1 / \mathrm{L \lambda})$

where: K1 (774.89), K2 (1321.08) - band-specific thermal conversion constants from the metadata

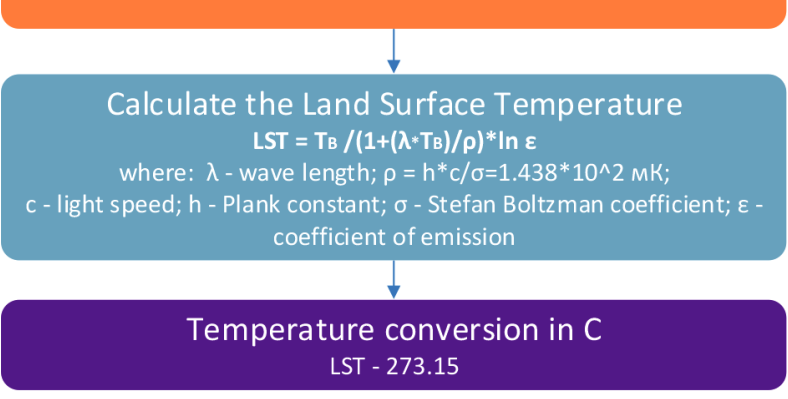

Figure 4. Sequence of conversion of source data into temperature values

The thickening of data was carried out on basis of the analysis of main components. The analysis of principle components (Principle Component Analysis - PCA) is the method of reducing the measurement of variables (channels) to principle components (Murai, 1993). Such transformation of principal components gives the full set of channels (principle components) which have the following characteristics: principle components do not correlate; each subsequent component has dispersion lesser than previous component. This method of singling out information and data THICKENING Is rather efficient (Ready \& Wintz, 1973).

At the stage of deciphering are established all types of covers present on the image. To determine the quantity of classes is used the previous classification of using noncontrolled algorithms (ISOCLUST, CLUSTER and others). After establishing the list of classes the determination is carried out of their exact deployment on the photo and the vectorization is implemented of reference plots.

Singled out reference plots are the basis for constructing files of signatures which contain the statistical information obtained by a spectral curve of each object. Later the analysis is carried out of such signatures. In case the scatterogram (Data Visualization Catalogue, n.d.) is built by vapors of channels showed their imposition other references are chosen.

At the stage of classification a thematic map is formed which visualizes all developed classes of their display. With the aim of removing noises in the form of solitary pixels it is also important to do filtration.

To single out purposeful plots on basis of formed classes is carried out re-classification. With the availability on images of objects of rad infrastructure and housing it is 


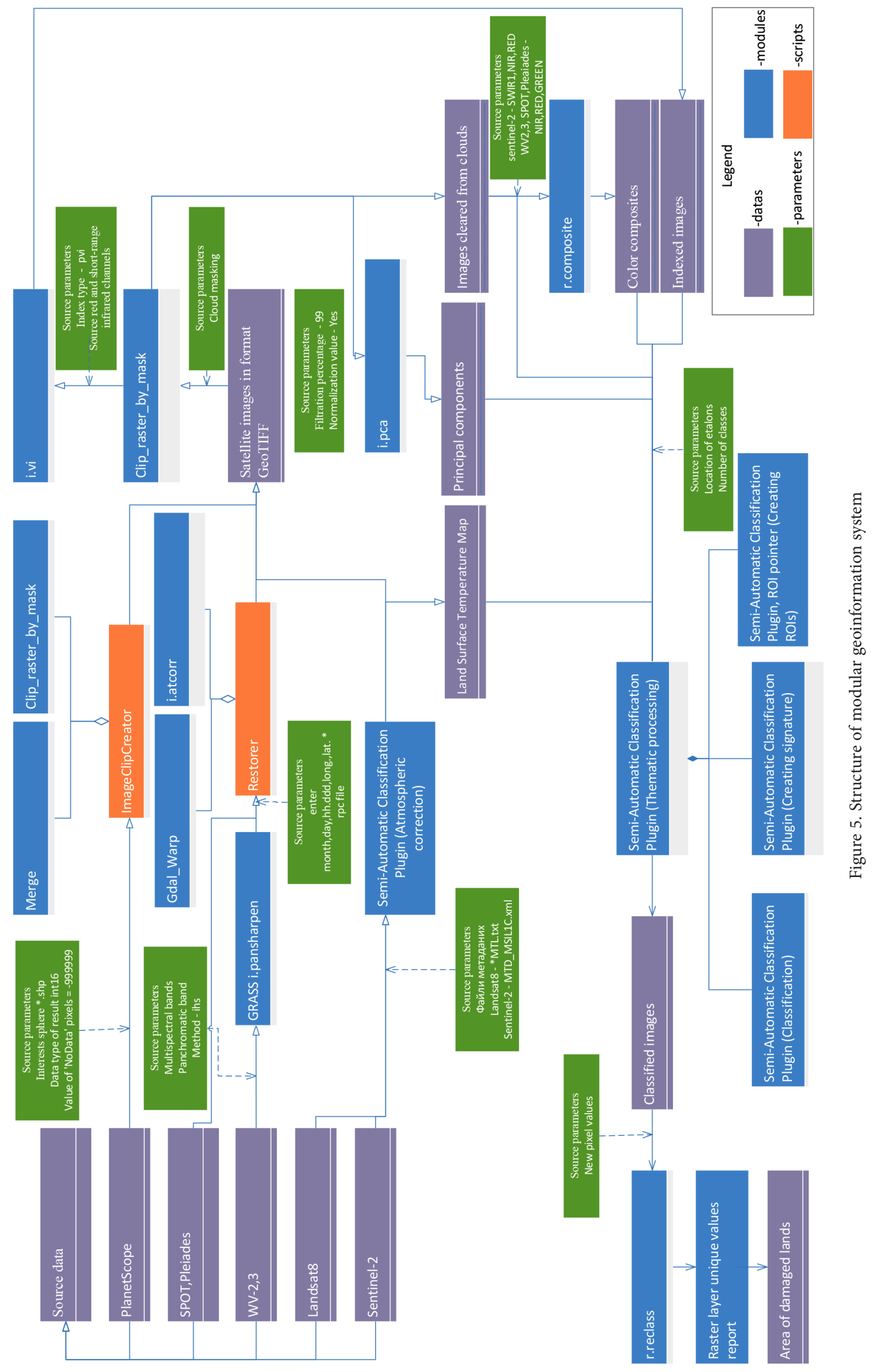


necessary to implement overlay operations with the aim of removing such objects as in some instances they have similar with open soils spectra; characteristics. At the final stage is carried out the repeated re-classification and the determination of areas identifies on the photo of damaged lands.

\section{The results of the research}

In the capacity of a basic desk GIS for implementing the proposed methodology the system QGIS 3.4.2 was used. The development of photos was carried out using both standard modules QGIS and also developed supplements. To spread possibilities of the system resources were drawn from a GDAL library (Geospatial Data Abstraction
Library [GDAL], n.d.), additional modules GRASS GIS (Geographic Resources Analysis Support System, n.d.) and GIS SAGA (SAGA GIS, n.d.).

The structure of a system with given source parameters for each stage of development is presented on Figure 5.

The result of work is the array of whole-numbered grids cells of which contain the information on pixel belonging to damaged lands. Considering various time distribution of source data there is the possibility to investigate the dynamics of changes.

On Figures 6-10 results are presented of automatic determination of damaged lands for the array No 1 (Sarny district). Areas of identified plots are given in Table 2. Differences in areas are caused by various time distribution of data and the difference in their space resolution.
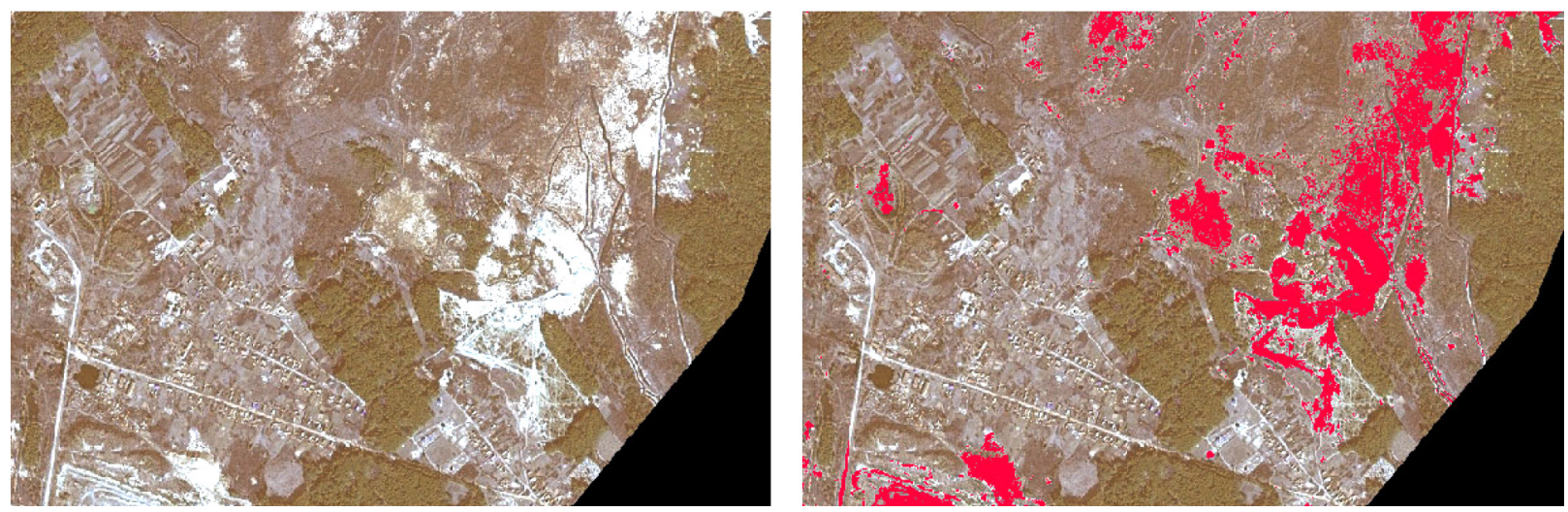

Figure 6. Results classified by SPOT-6 data
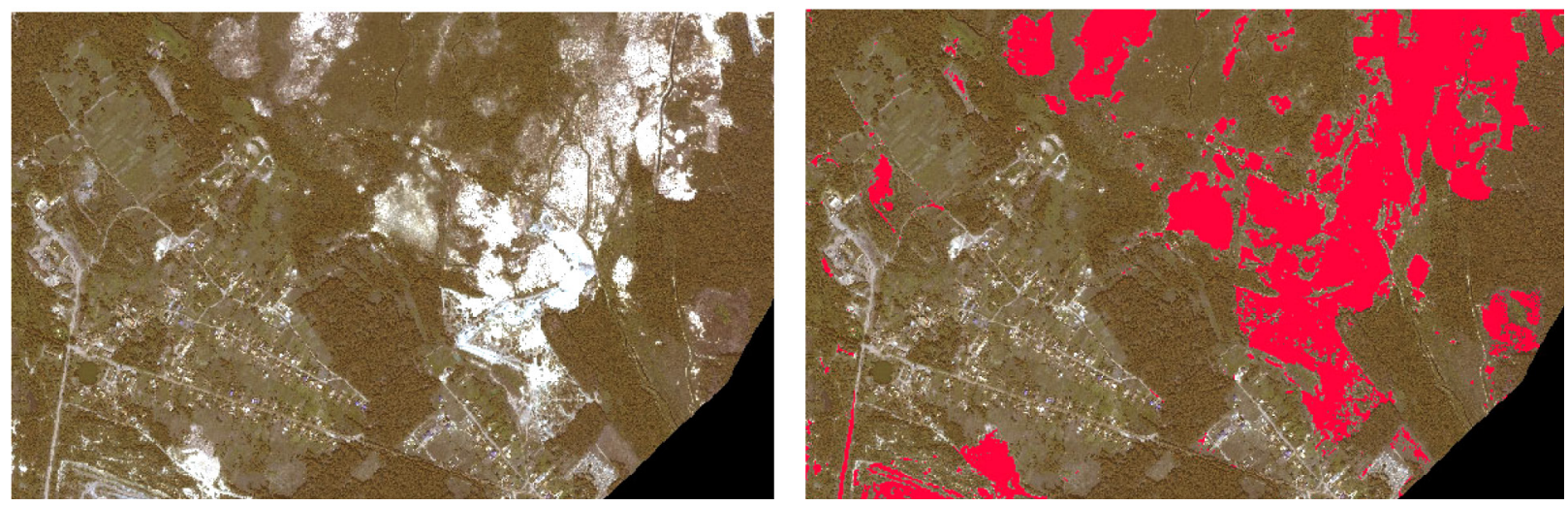

Figure 7. Results classified by Pleiades data
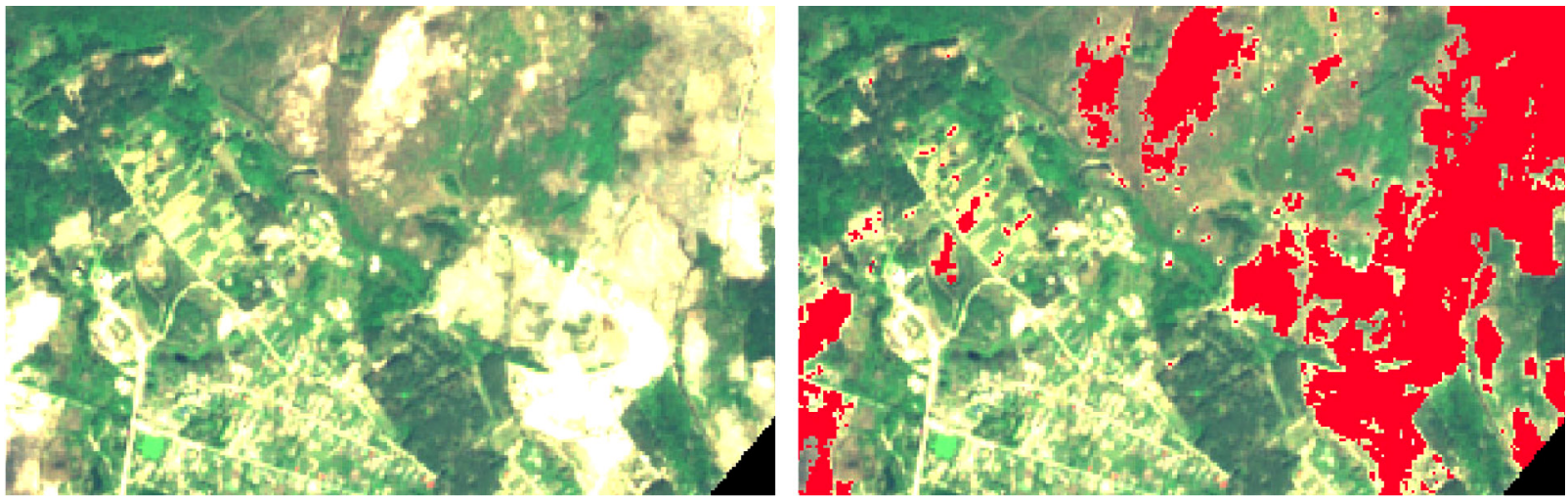

Figure 8. Results classified by Sentinel-2 data 

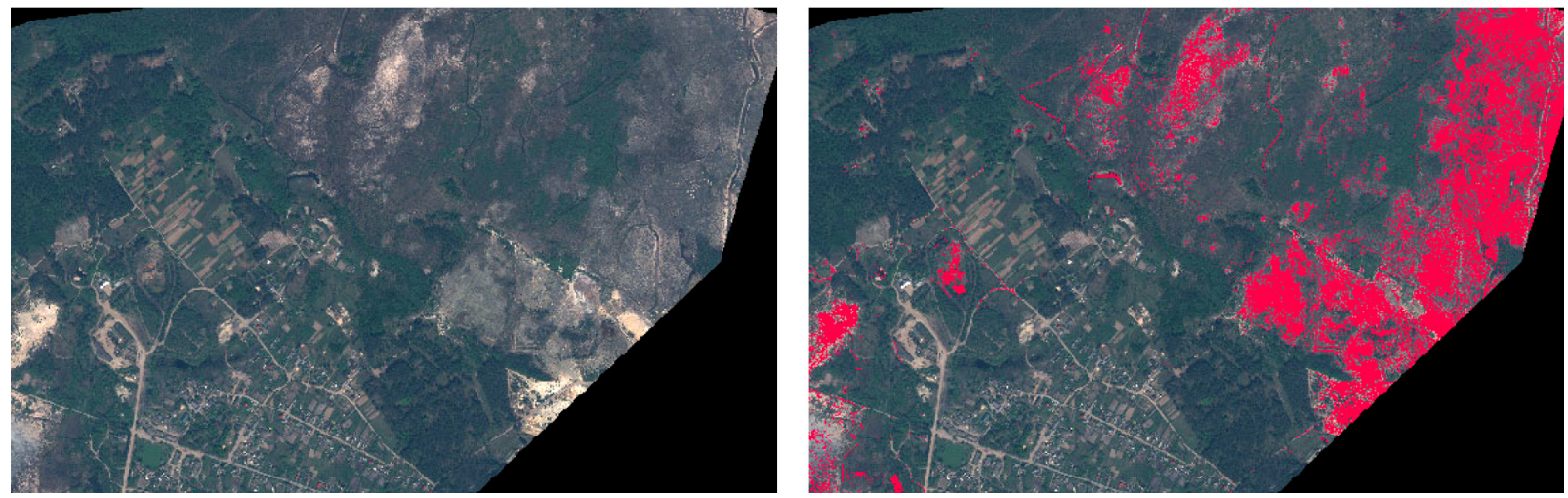

Figure 9. Result classified by WV-2 data
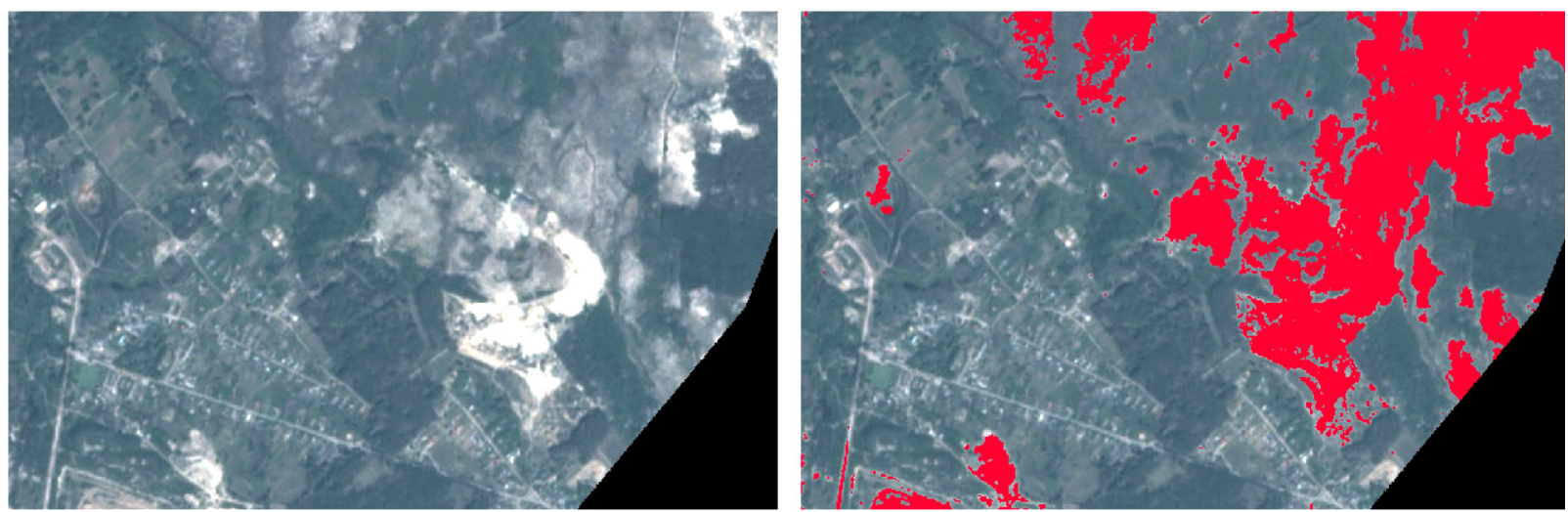

Figure 10. Results classified by PlanetScope data

Table 2. Areas of damaged lands by data of remote sensing of land on tested plot situated in Sarny district

\begin{tabular}{|c|l|c|c|}
\hline No & \multicolumn{1}{|c|}{$\begin{array}{c}\text { Satellite } \\
\text { system }\end{array}$} & $\begin{array}{c}\text { Date of } \\
\text { surveying }\end{array}$ & $\begin{array}{c}\text { Area of damaged } \\
\text { lands, ha }\end{array}$ \\
\hline 1 & Spot-6/7 & 24.03 .2015 & 385 \\
\hline 2 & Pleiades-1 & 20.08 .2016 & 597 \\
\hline 3 & WorldView-2 & 28.04 .2018 & 523 \\
\hline 4 & Sentinel-2B & 29.04 .2018 & 575 \\
\hline 5 & Planet Scope & 03.05 .2018 & 555 \\
\hline
\end{tabular}

\section{Conclusions}

Methods are developed of identifying lands damaged as a consequence of the illegal amber extraction taking into account the peculiarities of processing data from different types of surveying systems.

In the capacity of source data for the developed methods are used data of satellite surveying systems WorldView-2/3, Pleiades-1, Spot-6/7, Planet Scope, Sentinel-2B.

For testing five testing plots were chosen: four plots (arrays) are within boundaries of Rivne province, the fifth one - within boundaries of Zhytomyr province.

The structure is substantiated and modular geoinformation system is developed for identifying and temporal monitoring of damaged lands as a result of the illegal amber extraction. In the capacity of basic envelope of GIS is used free-of-charge program with an open code QGIS with added modules from open libraries GDAL and GRASS. Taking into account the specifics of processing data from different types of surveying systems block-schemes were formed of using GIS modules for WorldView-2/3, Peiades-1, Spot-6/7, Planet Scope, Sentinel-2B.

Testing was carried out of developed methods and modules of geoinformation system on researched tested plots with automatic identification and calculation of areas of damaged lands. For the verification of received results it is necessary to additionally conduct field works.

\section{Funding}

This work was supported by the Cabinet of Ministers of Ukraine order dated July 26, 2018 No. 543-r "On approval of a list of the most important scientific and technological (experimental) developments in the priority areas of science and technology development in the framework of the execution of the state order for the most important scientific and technological (experimental) developments and scientific and technical products in 2018-2019 years".

\section{Disclosure statement}

We not have any competing financial, professional, or personal interests from other parties. 


\section{References}

Data Visualization Catalogue. (n.d.). Diagram of dispersing. Retrieved February 10, 2019, from https://datavizcatalogue.com/ RU/metody/diagramma_rassejanija.html (in Russian).

ESA. (n.d.). SENTINEL Missions. Retrieved February 10, 2019, from https://sentinel.esa.int/web/sentinel/missions

Filipovych, V. Ye. (2015a). Operational control over spreading the illegal extraction of amber and evaluation of losses caused to state by materials of multi-zonal cosmic survey. Ecological Safety and Land Use, (4), 91-97 (in Ukrainian).

Filipovych, V. Ye. (2015b). Satellite monitoring of territories of illegal amber extraction. Ukrainian Journal of Remote Sensing of Earth, (6), 4-7 (in Ukrainian).

Filipovych, V. Ye., Krylova, G. B., \& Lubsky, M. S. (2015, October 5-9). Method of searching and localization of plots of illegal amber extraction by materials of multi-zonal cosmic survey. In Modern Information Technologies of Managing Ecological Safety, Land Use, Measures in Extraordinary Situations: Coll. of sc. papers of $14^{\text {th }}$ International sc.-prac. confer. (pp. 181198). Kyiv, Pushcha-Vodytsya (in Ukrainian).

Filipovych, V. Ye., \& Shevchuk, R. M. (2016). Methods and technology of assessing damage incurred to Ukrainian state as a result of illegal amber extraction. Ukrainian Journal of Remote Sensing of Earth, (11), 15-21 (in Ukrainian).

Geographic Resources Analysis Support System. (n.d.). Retrieved February 10, 2019, from https://grass.osgeo.org/

Geospatial Data Abstraction Library (n.d.). Retrieved February 10, 2019, from https://gdal.org/

Masley, V. I., Mozgovoy, D. K., Blousov, K. G., Khoroshilov, V. S., Bushanskaya, A. S., \& Galich, N. G. (2016). Methods of evaluating consequences of amber extraction by multispectral satellite photos. Cosmic Science and Technology, 22(6), 26-36 (in Russian). https://doi.org/10.15407/knit2016.06.026

Murai, S. (1993). Remote sensing note. Japan Association on Remote Sensing.
NASA. (n.d.). Thermal Infrared Sensor (TIRS). Retrieved February 10, 2019, from https://landsat.gsfc.nasa.gov/thermalinfrared-sensor-tirs/

Naumeth, T. A. (2014). Problems of using and organizing amber bearing territories of Ukrainian Polissya. Scientific Visnyk of Uzhgorod University. Series: Geography. Land Management. Nature Use, (3), 270-278. (in Ukrainian).

Okharev, V. O. (2016, August 22-27). Cosmic monitoring and geoinformation technologies in tasks of comprehensive evaluation of technogenic pollution of environment. In Theses of $16^{\text {th }}$ Ukrainian Conference on Cosmic Researches (p. 212). Odessa, Ukraine (in Ukrainian).

Pansharpening dannyh Landsat 8 sredstvami svobodnogo $P O$ [Pansharpening of Landsat 8 data by means of free software]. (n.d.). Retrieved February 10, 2019, from http://wiki.gis-lab. info/w/Паншарпенинг_данных_Landsat_8_средствами_ свободного_ПО (in Russian).

Prokopchuk, A., Yanchuk, O., \& Savytsky, A. (2018, December 13-15). Monitoring of surface temperature of water reservoircooler of Kmelnitsky APS by data of Landsat satellite. In International Scientific-Technical Conference of Young Scientists "GeoTerrace-2018" (pp. 142-143). Lviv, Ukraine (in Ukrainian).

Ready, P., \& Wintz, P. (1973, November). Information extraction, SNR improvement, and data compression in multispectral imagery. IEEE Transactions on Communications, 21(10), 1123-1131. https://doi.org/10.1109/TCOM.1973.1091550

SAGA GIS. (n.d.). Retrieved February 10, 2019, from http:// www.saga-gis.org/en/index.html

Yanchuk, R. M., Prokopchuk, A., \& Trokhymets, S. M. (2017). Identification and determination of areas of damaged as a result of amber extraction lands on basis of multi-zonal satellite photos of Sentinel-2. Present-Day Achievements of Geodetic Science and Production, (1(33)), 120-124 (in Ukrainian). 